\title{
Some Permanent Magnet Synchronous Motor (PMSM) Sensorless Control Methods based on Operation Speed Area
}

\author{
Bernadeta Wuri Harini \\ Universitas Sanata Dharma, Paingan, Maguwoharjo, Yogyakarta, 55282, Indonesia
}

\begin{abstract}
ARTICLE INFO
\section{Article history:}

Received April 05, 2021

Revised April 17, 2021

Accepted April 21, 2021

Keywords:

PMSM;

Permanent Magnet Synchronous Motor; Sensorless control;

Observer;

Operation speed area

ABSTRACT

This paper compares some sensorless Permanent Magnet Synchronous Motor (PMSM) controls for driving an electric vehicle in terms of operating speed. Sensorless control is a type of control method in which sensors, such as speed and position sensors, are not used to measure controlled variables. The controlled variable value is estimated from the stator current measurement. Sensorless control performance is not as good as a sensor-based system. This paper aims are to recommend a control method for the PMSM sensorless controls that would be used to drive an electric vehicle. The methods that we will discuss are divided into four categories based on the operation speed area. They are a startup, low speed, high speed, and low and high-speed areas. The low and high-speed area will be divided into with and without switching. If PMSM more work at high speed, the most speed area that is used, we prefer to choose the method that works at high speed, that is, the modification or combination of two or more conventional methods.
\end{abstract}

This work is licensed under a Creative Commons Attribution-Share Alike 4.0

Bernadeta Wuri Harini,

Sanata Dharma University, Paingan, Maguwoharjo, Yogyakarta, 55282, Indonesia

Email: wuribernard@usd.ac.id

\section{INTRODUCTION}

Permanent Magnet Synchronous Motor (PMSM) is widely used for an electric vehicle. It's because PMSM has several benefits. High performance, high torque, high power density, high power factor, greater torque inertia ratio, smaller size, lighter weight, lower current rating, and low vibration noise are some of the advantages [1]. Furthermore, alternating-current (AC) motors are used instead of direct-current (DC) motors in low and medium power control applications such as robotics and automobiles [2]. Compared to an induction motor, PMSM has better efficiency than an induction motor in power density and dynamic performance [3]. In general, there are two ways to control the speed or position of a PMSM: sensor control and sensorless control. The presence of a sensor (such as a speed or position sensor) can trigger issues when it comes to connecting the sensor to the motor. As a result, we employ the sensorless control system. The stator current is measured in the sensorless control method to estimate the motor speed. An observer is used to estimate the speed variable.

Unfortunately, using PMSM sensorless control in an electric vehicle can also trigger issues. The main issue with the PMSM sensorless control system is that the torque controller performance degraded when compared to a traditional controller with sensors, particularly at startup and low speeds [4]. When the PMSM runs at a low speed, the measured current signal is very weak, making current measurement difficult. This condition causes errors in estimating rotor angle. There are several methods for controlling the PMSM during low-speed operation. One of them is the high-frequency signals injection from the external as Jyoti Agrawal and Sanjay Bodkhe [5]. The measured current signal is very poor when the PMSM runs at a low speed, which makes current measurement difficult. This condition also occurs at startup. The availability of accurate rotor position information is the biggest problem in startup conditions. M. Arafa et al. [6] proposed a method to overcome this problem.

According to Gaeid, et al. [7], when the PMSM operates at high speeds, the sensorless control system's output is inferior to that of a control system with sensors. The paper explained that sensor-based controls 
produce a higher speed than sensorless control. In other words, the sensorless control system has some errors, especially when the motor is loaded.

Some researchers proposed sensorless PMSM control methods that can be used to control either at low or high speeds. Bobtsov Alexey A. et al. proposed a method of globally convergent position observer [8]. Mustafa Dursun et al. proposed a new adaptive design with a combination of two units fuzzy [9].

Some researchers proposed a method using switching to switch from a method at low-speed operation to high-speed operation. Siyi Chen et al. proposed a hybrid control scheme that separates the control at lowspeed and high-speed operation [10]. Some researchers proposed a method of smooth switching between the two methods. Antoni Arias et al. proposed a hybrid speed sensorless FOC (Field Oriented Control) system for estimating the model-based estimator angle and voltage test pulse injection angle estimator in four quadrants [11].

This paper aims are to recommend a control method for PMSM sensorless controls, which will be used to drive an electric vehicle. Sensorless motor control performance is not as good as a sensor-based system. This is a significant problem that occurs in most sensorless control system algorithms. This problem makes sensorless motor control until now has not been applied commercially in the industry. Completion of the algorithm is still being done today. Therefore, in this paper, we discuss some sensorless PMSM control methods and analyze the performance of each method. Several researchers reviewed sensorless control systems. Some of them are Singh, S. and Tiwari, A.N. [2], Wang, G. and Solsona, J. [12], Xu, D., et al. [13], and Zhang, G., et al. [14]. Singh, S. and Tiwari, A.N. classified the sensorless control based on the method scheme, i.e., methods of non-adaptive, adaptive, and methods based on saliency and signal injection [2]. Wang, G. and Solsona, J. reviewed some position sensorless control [12]. Xu, D. et al. presented the sensorless drives of induction motor and PMSM [13]. G. Zhang et al. presented a study of state-of-the-art position sensorless drive techniques focused on saliency-tracking methods [14]. The sensorless PMSM control methods are classified in this paper according to their operating speed range. Differs from the authors above, this paper also presents the combination of two or more methods.

\section{RESEARCH METHOD}

Fig. 1 shows the methodology of this review. In the introduction section above, we have explained the introduction and problem statement. In the second section, we present the method of review, sensorless control system, and classification of sensorless control system based on speed area, i.e., low speed, high speed, and both low and speed areas. In the discussion section, we will discuss the sensorless control methods that are explained in the second section. We will present in several tables as speed area they operate. The recommended method will be informed in the conclusion part.

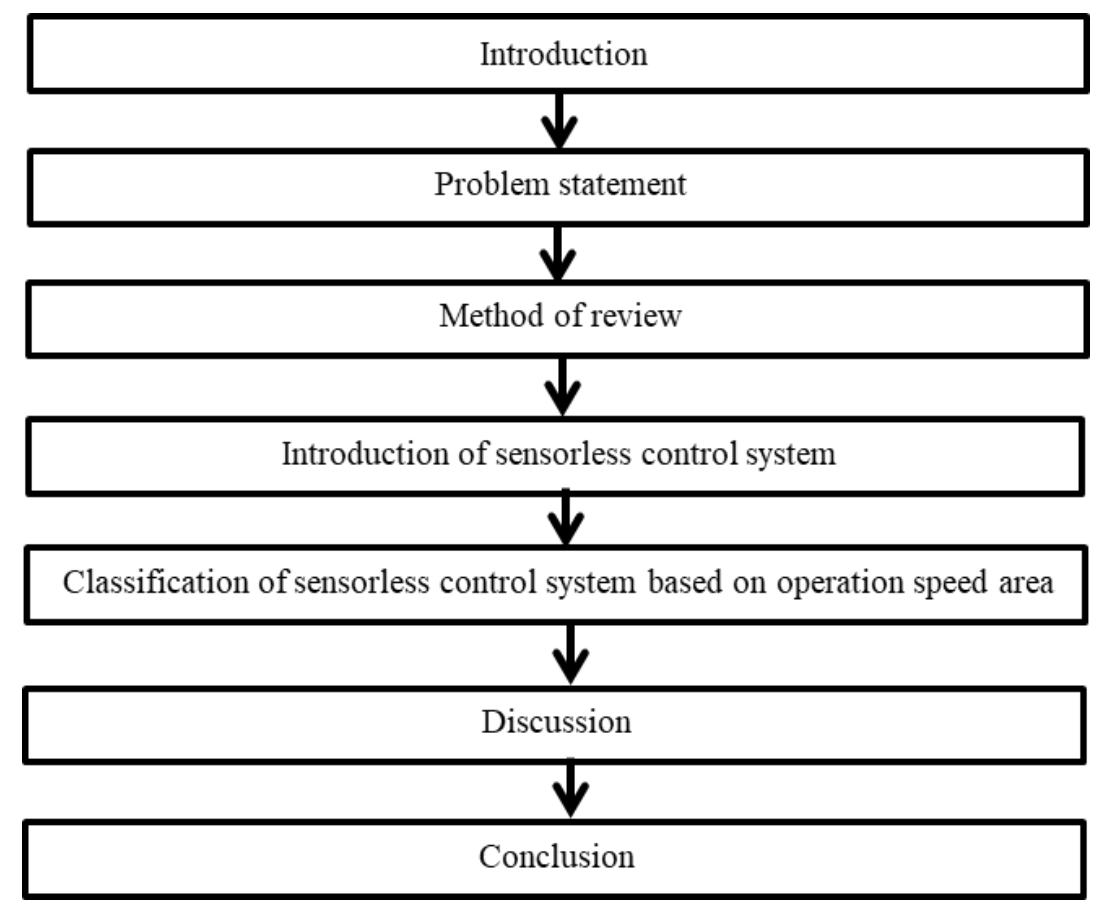

Fig. 1. Review method 
The sensorless control methods are divided into four categories based on operation speed to determine the control method recommendation for the PMSM sensorless controls that will be used to drive the electric vehicle. They are a startup, low speed, high speed, and low and high-speed areas. The low and high-speed areas will be divided into with and without switching methods. First, we will introduce the sensorless control system.

The block diagram of PMSM sensorless control is shown in Fig. 2 [15]. It consists of the $(a, b, c)$ to $(\alpha, \beta)$ Transformation (Clarke Transformation), the $(\alpha, \beta)$ to $(d, q)$ Transformation (Park Transformation), observer and Proportional and Integral (PI) controller [16].

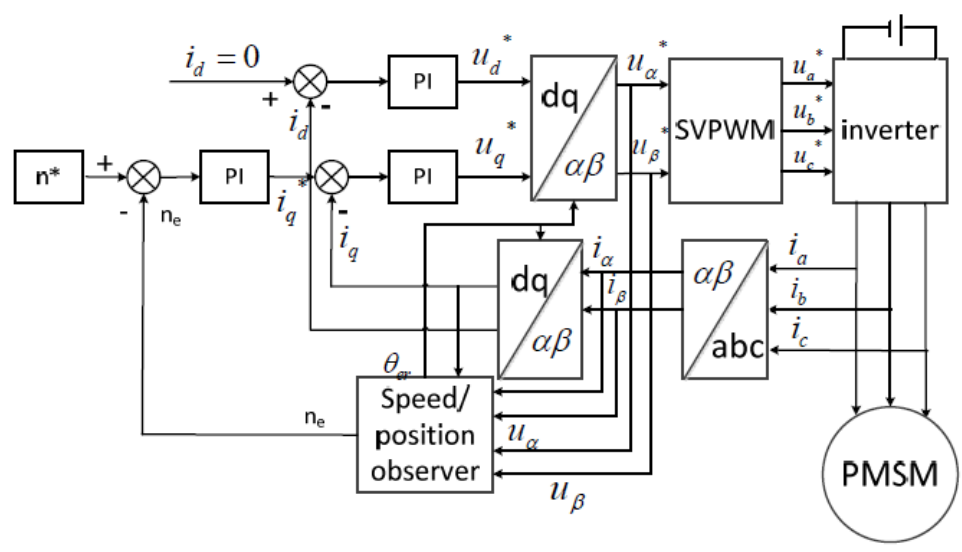

Fig. 2. PMSM sensorless control block diagram [15]

The PMSM sensorless control method is defined in detail in this section. According to Jyoti Sanjay Agrawal and Bodkhe [5], there are several control methods for the sensorless PMSM system. As shown in Fig. 3, sensorless control methods are divided into three categories: fundamental excitation methods, artificial intelligence methods, and signal injection methods.

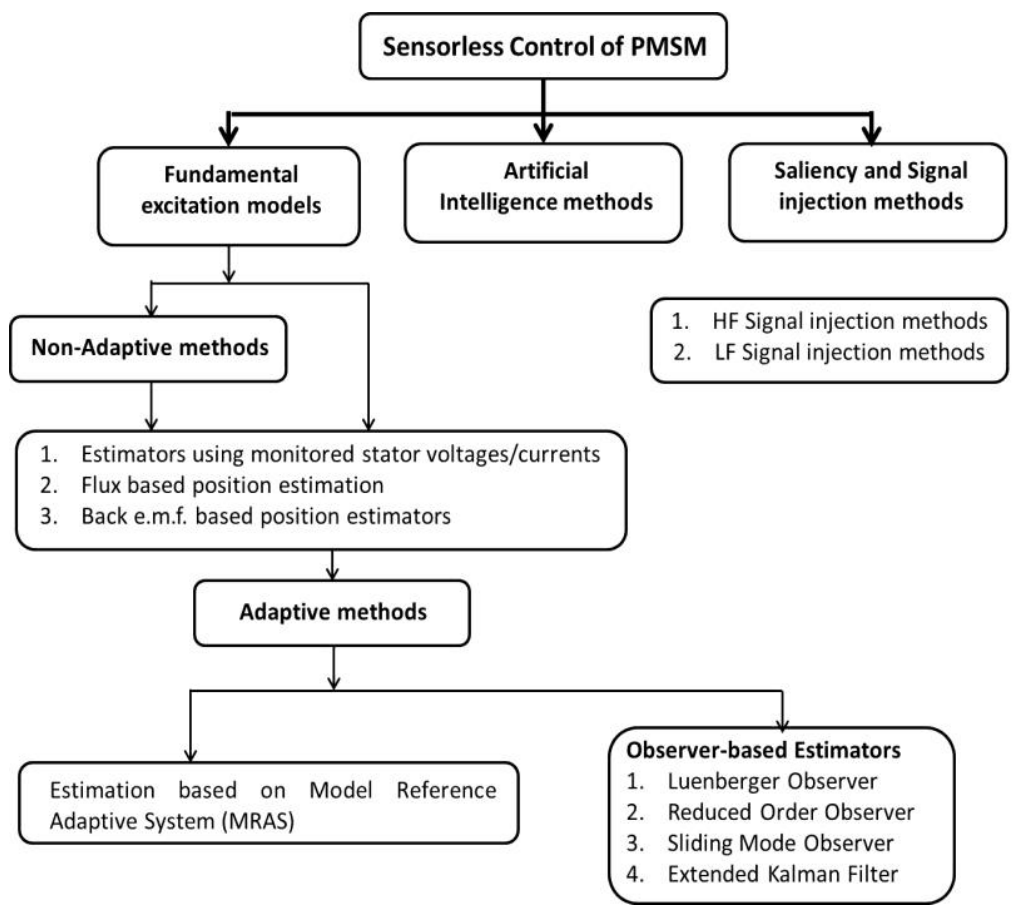

Fig. 3. Common sensorless control techniques for PMSM [5]

Differs from what is described by Jyoti Sanjay Agrawal et al., the PMSM sensorless control methods based on operation speed area will be discussed in this paper, which is divided into four categories (Fig. 4.). They are a startup, low speed, high speed, and low and high operation speed. 


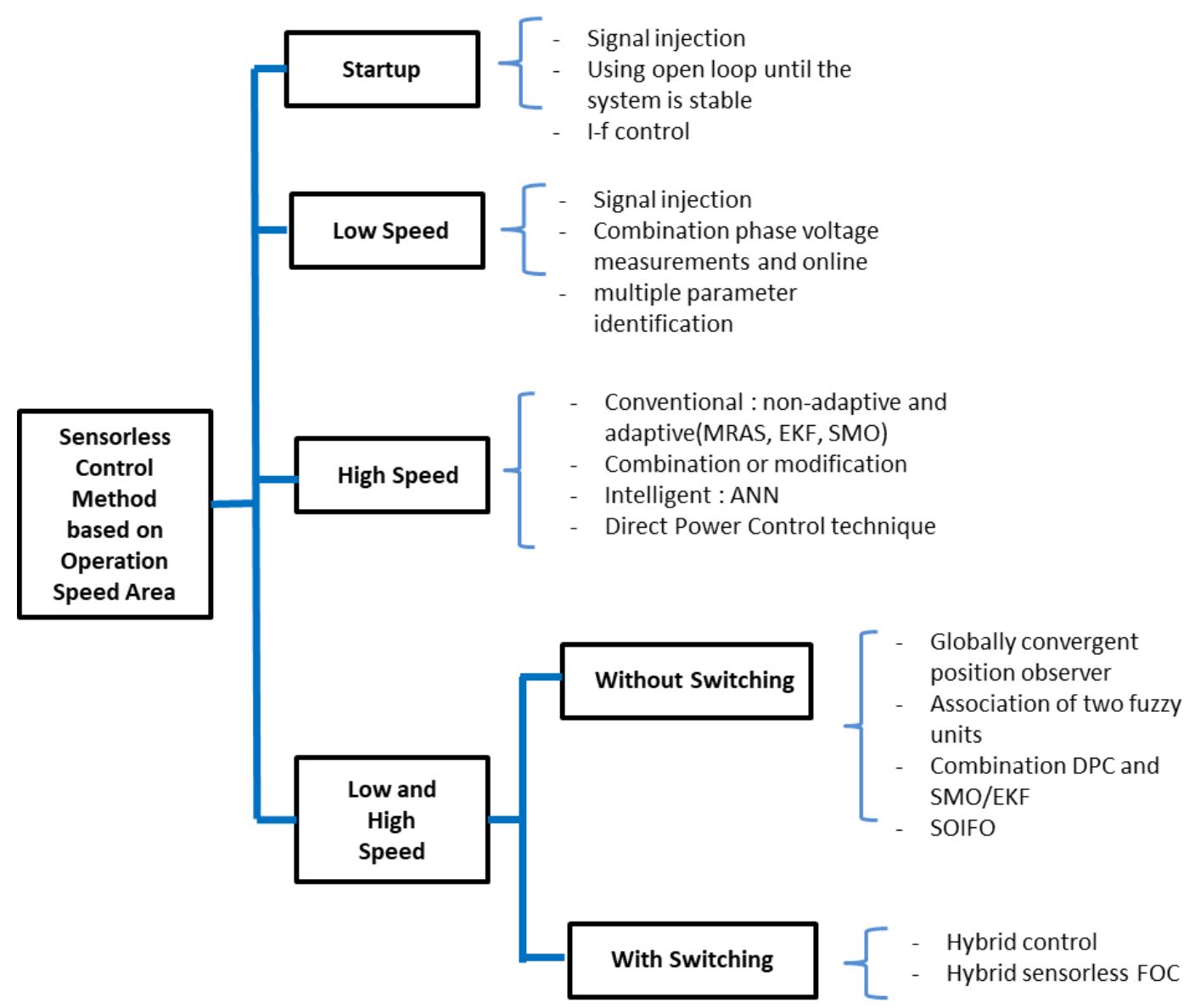

Fig. 4. Sensorless control methods based on speed area operation

\subsection{Startup}

In this paper, we specifically distinguish between startup conditions and low operation speed areas. The problem with the sensorless control method also occurs at startup. As stated in the introduction, the availability of correct rotor position information is an issue in startup conditions. M. Arafa et al. [6] proposed a method to overcome this problem. Control is started with the driver using open-loop current control at initialization before the observer calculates rotation and location stabilizes. After that, control is taken over by the rotary control loop using an observer who estimates the rotation and position of the rotor. The observer used is an adaptive Luenberger. The open-loop current control is used to observe the position differences. Before using the observer estimated position in vector control, the correction should be made. The observer requires stator current measurement. The system is simulated and verified experimentally. The system was tested for two load types, that is the type of fan type and roller. On acceleration of $100 \mathrm{~m} / \mathrm{s} 2$, the system successfully for the first load type in the initial position of $\pi / 3,2 \pi / 3$, $\pi$, and $5 \pi / 3$ but failed at the starting position of $4 \pi / 3$. For the second load type, the system successfully at startup in an early position of $\pi / 3,2 \pi / 3, \pi, 4 \pi / 3$, and $5 \pi / 3$. Suppose the rate of acceleration is reduced (e.g., $10 \mathrm{~m} / \mathrm{s} 2$ ), the system successful.

Luo, X. et al. [17] proposed injecting a high-frequency (HF) pulsating carrier voltage into a fixedfrequency rotating reference frame rather than the predicted synchronous reference frame (SRF). The device can be controlled once the polarity information is collected before the initialization. This system has a high signal-to-noise ratio when it comes to magnetic polarity detection. It also has a low level of vibration. The experimental results show that the rotor location performs well in both the steady-state and dynamic modes. To build a sensorless control system, Xing, J. et al. [18] proposed an I-f (current-frequency) startup process and a sliding mode observer. The paper proposed a simple and robust startup strategy with an adaptive compensator to achieve a smooth transition from I-f control to EMF-based control. Jin, X. et al. [19] uses RoTating Voltage Injection (RTVI) methods in a stationary reference frame to determine the initial rotor location at a standstill without the use of position sensors. Signal processing techniques are modified to get good performance. 


\subsection{Low-Speed Operation}

As startup condition, the main problem of sensorless control in low speed is the availability of information signal. With noises at a low speed, the back EMF cannot be precisely collected [20]. At low speeds, the back-EMF estimation scheme is unqualified. Therefore, to solve the lack of information signal at low speeds, some researchers suggested a sensorless control with external injection signals. Some of the researchers are Jyoti Sanjay Agrawal and Bodkhe [5], Xie, G., et al. [21], Wang, G. et al. [22], Wang, S., et al. [23], Li. H., et al. [24], and Scicluna, K., et al. [25]. The signal can be injected at a rotating reference frame $[21,22,24]$ or stationary reference frame [25]. Injecting a high-frequency signal into the estimate rotating reference frame is a technique proposed by Wang, S. [23]. The injected high-frequency current signal in the stationary reference frame, on the other hand, is used to determine rotor position.

Jyoti Sanjay Agrawal and Bodkhe [5] assessed the performance of sensorless control with external injection signals. The primary goal of the drive system is to maintain speed control in a low-speed setting. The sensorless control method proposed for PMSM can achieve high performance at low speeds but not at very high speeds. The error is pushed to zero when the method is checked with the phase modified from 50 $\mathrm{rad} / \mathrm{s}$ to $150 \mathrm{rad} / \mathrm{s}$, then $200 \mathrm{rad} / \mathrm{s}$ at $0.1 \mathrm{~s}$, and finally $250 \mathrm{rad} / \mathrm{s}$. It shows how well the position estimation scheme performs when operating at low speeds. This article does not discuss the system's performance when it is given a large load when the system is stable (steady-state condition). The method proposed by Luo, X. et al. [18] is also used for low-speed operation.

Recently, Wu C. et al. 1 [26] proposed another method of sensorless control for low-speed. The method is based on active flux (AF). The method is combined with online multiple parameter identification. The identification method is using an injection signal, too. To improve the precision of the location estimation, they proposed a new phase voltage measurement circuit.

\subsection{High-Speed Operation}

As is explained by Singh, S. et al. [2], the conventional methods that can be used in sensorless control at high speed can be a non-adaptive or adaptive method. The non-adaptive method is an open loop method, including the Direct Calculation method [27-29], the method based on a calculation of stator inductance [30], and Back EMF integration [31]. The adaptive method has a correction mechanism. The adaptive method consists of Model Reference Adaptive System (MRAS), Kalman and Extended Kalman Filters (EKF), and Sliding Mode Observer (SMO). Nowadays, so many researchers propose combining two or more methods or method modification for better performance. Then, it is used for estimation purposes. For example, many researchers use an MRAS as the basis for estimation [32-36]. Several investigators modified MRAS to reduce MRAS weakness [37-41].

Yousfi, D. et al. [42] compare three methods of PMSM drive location and speed estimation. Open-loop Flux Estimator-Based Technique, Flux Algebraic Estimation-Based Technique, and Reduced Flux ObserverBased Technique are the three techniques. The first technique's lowest sensorless speeds are 25 RPM, the second technique's lowest sensorless speeds are 30 RPM, and the third technique's lowest sensorless speeds are 33 RPM. So, all of them more suitable for high-speed operation. Q. Yuan et al. [15] use a modified integrator to integrate the stator EMF with the stator flux to estimate stator flux. This method is suitable for a speed above $200 \mathrm{rpm}$. For sensorless nonsinusoidal vector control of PMSM, Baratieri, C. et al. proposed a new discrete-time super-twisting sliding mode observer with variable gains [43]. With a maximum speed of $3000 \mathrm{rpm}$, this system is better suited for high-speed operation.

A sensorless PMSM drive based on Direct Power Control (DPC) has proposed by Zolfaghari, M. et al. [44]. A sensorless strategy was developed to estimate the rotor's position and speed of PMSM using an Artificial Neural Network (ANN). This technique is used to lower the drive's cost and improve its reliability. For DPC control PMSM drives, the proposed sensorless scheme employed an MRAS speed observer. The current model is used by the MRAS speed observer as an adaptive model. The Back Propagation Network algorithm was used to train the ANN online (BPN). The proposed method has a quick dynamic response, low ripples in currents, strength, and electromagnetic torque, according to simulation analysis. As a result, this approach is effective at monitoring speed and power references.

O. Aydogmus proposed A matrix converter that feeds a PMSM sensorless motor [45]. The method was created to demonstrate that by combining the benefits of matrix converters, permanent magnet synchronous motors, and sensorless power, a high-performance and efficient drive system can be built. EKF is used to power the motor without using any sensors. The promising results showed that EKF-based sensorless control of a matrix converter-fed PMSM drive system could achieve good performance at medium and high speeds. 


\subsection{Low and High-Speed Operation \\ 2.4.1. Without Switching}

Several methods are used to operate both at low and high speeds. Among them are proposed by Alexey A. Bobtsov et al., and Mustafa Dursun et al. Alexey A. Bobtsov et al. proposed a globally convergent observer position requiring only knowledge of the stator's resistance and inductance, as well as mechanical parameters and unknown magnetic flux constants [8]. The results of the simulation indicate that the error (flux, position, and velocity) is generated converging toward zero, although there are oscillations. The experimental results show some errors, although still small (not exceeding 60 to error position).

Mustafa Dursun et al. proposed a new adaptive design by combining two units of fuzzy [9]. Each module's rules are derived from the user interface and numerical data. The number of system variables, laws, and control variables increases the computational complexity of conventional fuzzy logic controllers. This would have affect the system's response time. The new system aims are to reduce the number of rules to a linear function of the system variable. As a result, the system's response time improves. The new approach is compared to conventional MRAS approaches using simulation and experimental data. The results show that the proposed approach is more efficient when it comes to speed tracking. Furthermore, compared to conventional approaches, the prediction accuracy is higher, and there are few oscillations. As a result, the proposed MRAS system can be used visibly and consistently. However, in this paper, this method has not been tested for the condition of large load changes.

Hasan, A.A., et al. proposed a control system that combined Direct Torque Control (DTC) and Sliding Mode Controller (SMC) [46]. The active flux principle is used to estimate the motor speed online. To substitute the hysteresis comparators and lookup table used in the traditional DTC, a torque/flux SMC and Space Vector Modulation (SVM) are used. SMC is proposed as a solution to the problem of achieving phase stability. The proposed scheme does not require any additional complicated algorithms when operating at very low speeds. It also does not necessitate signal injection schemes. The results show that the proposed scheme performs well at a standstill, low and high speeds, with load disturbance and parameter variance. At $100 \mathrm{RPM}$, the speed error is less than 0.5 percent. The speed error is approximately $3 \mathrm{rpm}$ ( 0.2 percent) at high speeds, rising to $5 \mathrm{rpm}(0.33 \%)$ as the stator resistance increases.

Kim, H., et al. proposed a strategy of sensorless speed control for a PMSM based on a new SlidingMode Observer (SMO), which replaces the signum function of a variable boundary layer with a sigmoid function [47]. The researchers proposed a high-speed SMO that is resistant to parameter shifts and disturbances. The back EMF is used by the machine to calculate the rotor position and angular velocity. A low-pass filter and additional rotor location compensation are used in the traditional SMO to minimize the chattering problem observed in the SMO. The switching mechanism is implemented using a sigmoid function. The low-pass filter causes a time delay, which must be resolved. The SMO's steady-state efficiency is expected to increase as the stator resistance varies. The proposed SMO's stability was tested using the Lyapunov second process. The proposed SMO has a settling period of $350 \mathrm{~ms}$ at $500 \mathrm{rpm}$, compared to 400 $\mathrm{ms}$ for the traditional one. The proposed observer has a $450-\mathrm{ms}$ settling time for the $2000-\mathrm{r} / \mathrm{min}$ speed process, while the traditional observer has a 550-ms settling time. Unfortunately, there is still a $20 \%$ overshoot with this approach.

Jarzebowicz, L. et al. proposed a sensorless algorithm for the emergency control of an IPMSM drive in an electric or hybrid vehicle [48]. Two rotor-position estimators based on Derivatives of Motor Phase Currents are used in the proposed algorithm (DMPCs). The algorithm is tested in three different emergency scenarios. The machine operates at near-zero speed with the maximum torque relation in the first state. The current IQ variations between positive, zero, and negative values, which correspond to propelling, freewheeling, and splitting, are the second scenario. No additional load torque is applied in this case. The third case involves a resolver failure.

E.G. Shehata suggested using Direct Torque Control to speed sensorless control of an Interior Permanent Magnet Synchronous Motor (IPMSM) (DTC) [49]. The IPMSM's rotor speed and location are calculated using an active flux principle, in which the active flux vector position is the same as the rotor position. Even at very low speeds, the proposed algorithm does not require a high-frequency injection signal or complicated schemes. A combination of torque/ flux sliding mode controller (SMC) and space vector modulation is proposed to boost the efficiency of the traditional DTC. For a stator flux and electromagnetic torque estimation, the stator resistance value is needed. The output of the scheme degrades as temperature or frequency varies, particularly at low speeds. A reduced-order extended Kalman filter (EKF) is proposed to update the stator resistance online to solve this problem. The proposed scheme incorporates the benefits of direct torque control, sliding mode controller, and sensorless speed control. The results show that the scheme can operate at a wide range of speeds with load disturbances and parameter changes. 
For sensorless PMSMs with unknown load torque, Bifaretti, S. proposed nonlinear speed tracking control [50]. For the first nonlinear adaptive control, simulation and experimental results are shown. Even though the proposed approach has a high overshoot in low-speed service, it achieves satisfactory results in practice.

Accetta, A. et al. proposed the PMSM space-vector equations. The algorithm has collaborated in a matrix form. This form permits using a Least Squares technique (LST) to estimate the PMSM speed [51]. The TLS EXIN neuron, which is the only linear neural network capable of solving the TLS problem online in a recursive manner, was then used to tackle the problem. An advanced test set-up based on a fractional horsepower permanent magnet machine was used to conduct the experiments. The estimated position tracks the measured one at low speeds with no load, with an estimation error rising marginally during the speed transient and settling to a constant value at steady-state speed. The method is verified by the speed estimation error waveform, which is almost null on average at high speed with no load and load. Only during the fast transient does it reach high values.

Yoshitaka Iwaji et al. proposed another method using a neutral stator voltage [52]. Detecting the neutral voltage at zero speed can be used to measure the rotor position. This method is used to overcome the weaknesses of the signal injection method in which the signal injection method causes electromagnetic noise. The method is validated for low and high speeds and a load of 50\% and $100 \%$. This method assumed that the neutral voltage depends on self-inductance changes but did not pay attention to the influence of mutual inductance. This method has not been used in the vector control algorithm.

Due to initial rotor flux, detection errors, and other factors, the rotor flux estimation method has dc offset and harmonics problems. $\mathrm{Xu}, \mathrm{W}$. et al. suggested an enhanced nonlinear flux observer for sensorless monitoring of PMSM to remove these flaws [53]. They suggested two new flux observers for PMSM rotor flux estimation: the second-order generalized integral flux observer (SOIFO) and the second-order SOIFO. The dc part of the SOIFO can be limited to a specific value. Without magnitude and phase compensation, the dc offset and harmonics of calculated rotor flux can be removed. As a result, the speed and rotor position can be reliably estimated.

\subsubsection{With Switching}

Some researchers proposed sensorless control using a switching method to switch from the method at low speed to high speed. Siyi Chen et al. proposed a hybrid control scheme that separates the control at low speed and high speed [10]. At low-speed mode, control strategy proposed using V/F constant. In high-speed mode proposed using Sliding Mode Controller (SMC). This paper proposed a method that has smooth switching between the two methods. The difference between the desired and actual speeds is very small. However, particularly at low speeds, there is still a difference between the actual and estimated rotor position. This is because the motor speed is hard to count, so the mode V/F is constant only on the motor's condition when it starts or when switching to the opposite.

Besides Siyi Chen et al., Antoni Arias et al. also proposed using a switching method to move from low speed to high speed. Antoni Arias estimates the angle of the model-based estimator angle and voltage test pulse injection angle estimator using hybrid speed sensorless FOC (Field Oriented Control) 4 quadrants [11]. At low speed, the estimation uses injection techniques, while at high speed, the estimation uses model-based estimation. The transition between the two estimations is smoothed using a predetermined formula. The simulation results with Matlab/Simulink are \pm 4.5 electrical degree angles ( \pm 1.5 mechanical degrees) errors. When the motor is loaded, large errors occur, especially when operated at high speeds. For PMSM drives, Li, H. et al. [54] suggested a hybrid sensorless control based on I/F and SMO using current nonlinear regulation. Compound control switching is a smooth operation. At medium and high speeds, the sliding control algorithm is used. The algorithm employs I/F for zero and low speeds.

\section{DISCUSSION}

From the discussion above, it can be arranged the table of PMSM sensorless control method review, as shown in Table $1-5$. Table 1 shows the sensorless control methods of PMSM at startup conditions. Table 2 shows the sensorless control methods of PMSM at low operation speed. Table 3 shows the sensorless control methods of PMSM at high operation speed. Table 4 shows the sensorless control methods of PMSM at low and high operation speed without switching. Table 5 shows the sensorless control methods of PMSM at low and high operation speed with switching.

The method chosen depends on the desired motor speed. If the motors are working at a startup and low speed, then the method by injection techniques can be selected then the back EMF signal. In low-speed operation, however, the sensorless drive's output is frequently affected by voltage error induced by inverter

Some Permanent Magnet Synchronous Motor (PMSM) Sensorless Control Methods based on Operation Speed Area (Bernadeta Wuri Harini) 
nonlinearities [55]. The injected voltage vector may not be positioned on the target axis as a result of the inverter voltage error, leading to an estimation error. The injection signal injects into a stationary reference frame is better than a rotating reference frame. Working in a rotating reference frame can make some errors [56]. Assume the signal is injected into the estimated d-q rotating reference frame. In that case, the injected high-frequency current signal in the stationary reference frame can be used to determine the rotor position. It is superior to the d-q rotating reference frame in that it avoids applying to PMSMs that have no apparent salient pole effect, as suggested by Wang, S. et al. [23]. If the startup condition is critical, and I-f (currentfrequency) startup approach should be used, and a sliding mode observer should be used to create a sensorless control device.

There are so many methods in sensorless control systems that work at high speed. Some conventional methods are MRAS, EKF, and SMO. Although many researchers have proposed new methods to estimate rotation or position, MRAS is still widely used today. This is due to the fact that MRAS is a fairly mature cycle identification tool [36]. Through an adaptive design, MRAS can ensure system stability and render error signals inclined to zero, ensuring accurate rotation estimation. However, MRAS also has a weakness, i.e., the time delay and the error in estimating the rotation at the startup stage and when getting a load torque [29]. Many researchers use MRAS as the basis for estimation [32-35]. Besides, several investigators modified MRAS to reduce MRAS weakness [37-41]. Until now, EKF and SMO are still used in the sensorless control system. The EKF is reliant on weak flux linkage failures, and it performs poorly at lower speeds [2]. SMO is a popular technique because it has robust property towards parameter variation, but we have to choose gain coefficients to get good speed estimation results. Some so many researchers modify or combine EKF and SMO to control the sensorless control system.

When the motor is used at both low and high speed, the hybrid control method with a combination of the I/ F constant and SMO with a smooth switching process can be used. The current development of researchers proposes more modification of the control method without switching. Since motors are widely used for high speed, a method for controlling PMSM at high speed can be selected to simplify the process. The method chosen is a method that has a computational process that is not too complex. Methods that are not simple will affect the control process. This can be obtained by modifying the old methods according to the needs. However, because all the methods described above are not tested on the same motor, then to get validated comparisons.

Table 1 Sensorless Control Methods of PMSM at startup condition

\begin{tabular}{|c|c|c|c|}
\hline $\begin{array}{c}\text { Authors, } \\
\text { Years }\end{array}$ & Method & Advantages & Disadvantages \\
\hline$[6], 2016$ & $\begin{array}{l}\text { The control is taken over by } \\
\text { the rotary control loop using a } \\
\text { Luenberger observer who } \\
\text { estimates the rotation and } \\
\text { position of the rotor, using the } \\
\text { open-loop current control } \\
\text { before the observer estimates } \\
\text { rotation and position stabilize. }\end{array}$ & $\begin{array}{l}\text { Can overcome the initial position } \\
\text { differences. }\end{array}$ & $\begin{array}{l}\text { - Open-loop control } \\
\text { must be switched to } \\
\text { closed-loop control. } \\
\text { - It's with the initial } \\
\text { position estimation. } \\
\text { - It is failed at the } \\
\text { starting position of } \\
4 \pi / 3 \text {. }\end{array}$ \\
\hline [17], 2016 & $\begin{array}{l}\text { Inject an HF carrier voltage at } \\
\text { startup condition to detect } \\
\text { magnetic polarity. }\end{array}$ & It doesn't need switching control. & $\begin{array}{l}\text { It needs a signal } \\
\text { injection. }\end{array}$ \\
\hline [18], 2020 & $\begin{array}{l}\text { An I-f (current-frequency) } \\
\text { startup method and a sliding } \\
\text { mode observer are used to } \\
\text { create a sensorless control } \\
\text { device }\end{array}$ & $\begin{array}{l}\text { - The transition from I-f control } \\
\text { to EMF-based control is } \\
\text { smooth. } \\
\text { - It is without initial position } \\
\text { estimation. }\end{array}$ & $\begin{array}{l}\text { No-load torque } \\
\text { information is applied to } \\
\text { test the method. }\end{array}$ \\
\hline [19], 2018 & $\begin{array}{l}\text { Methods of High-Frequency } \\
\text { Voltage-Injection and Design } \\
\text { of Observer for Detecting } \\
\text { Initial Position }\end{array}$ & $\begin{array}{l}\text { - It reduces the effects because of } \\
\text { voltage-injection errors }\end{array}$ & It didn't test under load \\
\hline
\end{tabular}


Table 2 Sensorless Control Methods of PMSM at low operation speed

\begin{tabular}{|c|c|c|c|}
\hline $\begin{array}{l}\text { Authors, } \\
\text { Years }\end{array}$ & Method & Advantages & Disadvantages \\
\hline$[5], 2015$ & External injection signal & $\begin{array}{l}\text { the error is driven to zero, good at } \\
\text { low-speed operation (below } 250 \\
\text { RPM) }\end{array}$ & $\begin{array}{l}\text { Did not discuss the } \\
\text { performance of the } \\
\text { system when it is given a } \\
\text { large load when the } \\
\text { system is stable }\end{array}$ \\
\hline$[17], 2016$ & $\begin{array}{l}\text { Inject an HF carrier voltage at } \\
\text { startup condition to detect } \\
\text { magnetic polarity. }\end{array}$ & $\begin{array}{l}\text { Capable of persisting low speed } \\
\text { with a high dynamic load } \\
\text { condition. }\end{array}$ & $\begin{array}{l}\text { Dynamic performance } \\
\text { under step full-load and } \\
\text { step speed have errors. }\end{array}$ \\
\hline $\begin{array}{l}{[21], 2016} \\
{[22], 2017} \\
{[24], 2019}\end{array}$ & $\begin{array}{l}\text { External injection signal in } \\
\text { rotating reference frame }\end{array}$ & $\begin{array}{l}\text { Capable of controlling sensorless } \\
\text { system at low speed }\end{array}$ & $\begin{array}{l}\text { - Must generate } \\
\text { injection signal } \\
\text { - Work at rotating frame } \\
\text { can make some errors }\end{array}$ \\
\hline$[23], 2019$ & $\begin{array}{l}\text { In the rotating reference } \\
\text { frame, an external injection } \\
\text { signal is used, but the rotor } \\
\text { position is obtained from the } \\
\text { injected high-frequency } \\
\text { current signal in the stationary } \\
\text { reference frame. }\end{array}$ & $\begin{array}{l}\text { - Capable of controlling } \\
\text { sensorless system at low } \\
\text { speed } \\
\text { - rotor position information at } \\
\text { the stationary reference } \\
\text { frame can help prevent } \\
\text { failure }\end{array}$ & $\begin{array}{l}\text { Must generate injection } \\
\text { signal }\end{array}$ \\
\hline$[25], 2020$ & $\begin{array}{l}\text { The external signal is injected } \\
\text { into a stationary reference } \\
\text { frame }\end{array}$ & $\begin{array}{l}\text { Capable of controlling sensorless } \\
\text { system at low speed }\end{array}$ & $\begin{array}{l}\text { Must generate injection } \\
\text { signal }\end{array}$ \\
\hline$[26], 2020$ & $\begin{array}{l}\text { The combination between } \\
\text { measurement of phase voltage } \\
\text { and online identification for } \\
\text { multiple parameters }\end{array}$ & $\begin{array}{l}\text { - Capable of controlling } \\
\text { sensorless system at low } \\
\text { speed } \\
\text { - Work at the stationary } \\
\text { reference frame }\end{array}$ & $\begin{array}{l}\text { Must generate injection } \\
\text { signal }\end{array}$ \\
\hline
\end{tabular}

Table 3 Sensorless Control Methods of PMSM at high operation speed

\begin{tabular}{|c|c|c|c|}
\hline $\begin{array}{c}\text { Authors, } \\
\text { Years }\end{array}$ & Method & Advantages & Disadvantages \\
\hline $\begin{array}{l}{[28], 2007} \\
{[29], 2020}\end{array}$ & Direct Calculation method & Simple computation & $\begin{array}{ll}\text { No } & \text { correction } \\
\text { mechanism } & \end{array}$ \\
\hline $\begin{array}{l}{[33], 2019} \\
{[36], 2012}\end{array}$ & Based on MRAS & There is an adaptive mechanism & $\begin{array}{l}\text { The computation is more } \\
\text { complex than } \\
\text { conventional MRAS }\end{array}$ \\
\hline $\begin{array}{l}{[37], 2016} \\
{[38], 2018} \\
{[39], 2019}\end{array}$ & Modified MRAS & $\begin{array}{l}\text { The performance is better than } \\
\text { conventional MRAS }\end{array}$ & $\begin{array}{l}\text { The computation is more } \\
\text { complex than } \\
\text { conventional MRAS }\end{array}$ \\
\hline [43], 2016 & Modified SMO & $3000 \mathrm{rpm}$ maximum speed & $\begin{array}{l}\text { The computation is more } \\
\text { complex than } \\
\text { conventional SMO }\end{array}$ \\
\hline [44], 2016 & $\begin{array}{l}\text { Direct Power Control (DPC) } \\
\text { technique }\end{array}$ & $\begin{array}{l}\text { - Use MRAS speed observer } \\
\text { and ANN. } \\
\text { - The performance in tracking } \\
\text { speed and power references is } \\
\text { good. }\end{array}$ & $\begin{array}{l}\text { The computation is more } \\
\text { complex }\end{array}$ \\
\hline [45], 2012 & $\begin{array}{l}\text { Sensorless control of matrix } \\
\text { converter fed PMSM drive } \\
\text { using EKF }\end{array}$ & $\begin{array}{l}\text { The performance at medium and } \\
\text { high-speed operations is good }\end{array}$ & $\begin{array}{l}\text { The computation is more } \\
\text { complex than } \\
\text { conventional EKF }\end{array}$ \\
\hline
\end{tabular}


Table 4 Sensorless Control Methods of PMSM at low and high operation speed without switching

\begin{tabular}{|c|c|c|c|}
\hline $\begin{array}{c}\text { Authors, } \\
\text { Years }\end{array}$ & Method & Advantages & Disadvantages \\
\hline$[8], 2015$ & $\begin{array}{l}\text { Globally convergent position } \\
\text { observer }\end{array}$ & $\begin{array}{l}\text { - only requires knowledge of the } \\
\text { resistance and inductance of } \\
\text { the stator } \\
\text { - error (flux, velocity, and } \\
\text { position) is converging toward } \\
\text { zero }\end{array}$ & $\begin{array}{l}\text { there are } \\
\text { oscillations. }\end{array}$ \\
\hline [9], 2016 & $\begin{array}{l}\text { Adaptive design with two } \\
\text { units fuzzy combination }\end{array}$ & $\begin{array}{l}\text { The response is faster than } \\
\text { traditional MRAS }\end{array}$ & $\begin{array}{l}\text { The method has not been } \\
\text { tested for the condition } \\
\text { of large load changes. }\end{array}$ \\
\hline [46], 2012 & 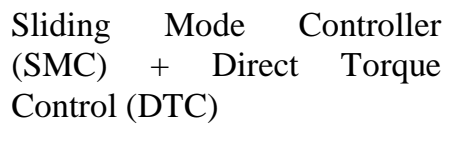 & $\begin{array}{l}\text { high performance at all speeds, } \\
\text { including the variation of } \\
\text { parameter and disturbance of } \\
\text { load. }\end{array}$ & $\begin{array}{l}\text { Higher speed, bigger } \\
\text { speed error }\end{array}$ \\
\hline [47], 2011 & $\begin{array}{l}\text { Sliding Mode Observer } \\
\text { (SMO), which uses a variable } \\
\text { boundary layer instead of a } \\
\text { sigmoid feature. }\end{array}$ & $\begin{array}{l}\text { Settling time is faster than the } \\
\text { conventional method }\end{array}$ & $\begin{array}{l}\text { this method still } \\
\text { produces a } 20 \% \\
\text { overshoot. }\end{array}$ \\
\hline [49], 2013 & $\begin{array}{l}\text { A reduced-order extended } \\
\text { Kalman filter }(\mathrm{EKF})+\text { Direct } \\
\text { Torque Control (DTC) }\end{array}$ & $\begin{array}{l}\text { - Reduced EKF is used to update } \\
\text { online the stator resistance } \\
\text { - Validated at wide range speed } \\
\text { with disturbance of load and } \\
\text { variation of parameters }\end{array}$ & $\begin{array}{l}\text { The computation is more } \\
\text { complex }\end{array}$ \\
\hline [53], 2018 & $\begin{array}{l}\text { second-order } r \text { generalized } \\
\text { integral flux observer } \\
\text { (SOIFO) and second-order } \\
\text { SOIFO for the rotor flux } \\
\text { estimation }\end{array}$ & $\begin{array}{l}\text { The speed and rotor position can } \\
\text { be estimated accurately. }\end{array}$ & $\begin{array}{l}\text { The computation is more } \\
\text { complex }\end{array}$ \\
\hline
\end{tabular}

Table 5 Sensorless Control Methods of PMSM at low and high operation speed with switching

\begin{tabular}{|c|c|c|c|}
\hline $\begin{array}{l}\text { Authors, } \\
\text { Years }\end{array}$ & Method & Advantages & Disadvantages \\
\hline$[10], 2015$ & $\begin{array}{l}\text { V/F constant }+ \text { Sliding Mode } \\
\text { Controller }(\mathrm{SMC}) .\end{array}$ & $\begin{array}{l}\text { - Hybrid control with smooth } \\
\text { switching } \\
\text { - V/F constant at low-speed } \\
\text { mode } \\
\text { - Sliding Mode Controller (SMC) } \\
\text { is at high-speed mode. }\end{array}$ & More complex algorithm \\
\hline$[11], 2013$ & $\begin{array}{c}\text { Injection technique + FOC } \\
\text { (Field Oriented Control) } 4 \\
\text { quadrants }\end{array}$ & $\begin{array}{l}\text { - Hybrid control with switching } \\
\text { - Injection technique at low- } \\
\text { speed mode } \\
\text { - FOC at high-speed mode. }\end{array}$ & Large error at high speed \\
\hline$[54], 2019$ & $\begin{array}{l}\text { hybrid sensorless control } \\
\text { using I/F and SMO using } \\
\text { current nonlinear regulation }\end{array}$ & Smooth switching process & More complex algorithm \\
\hline
\end{tabular}

As an asynchronous motor, PMSM must operate in all load conditions with synchronous speed. Motors can lose synchronization if the motor's mechanical load increases and can even cause the motor to stop [57, 58]. The synchronization loss because of load with torque exceeds the allowable motor torque is one of the PMSM sensorless control problems. MRAS isn't capable of detecting the synchronization loss [29]. Most methods didn't test by the big load. The challenging future work is to test the above methods using the load with torque exceed the allowable motor torque. 


\section{CONCLUSION}

The selection of appropriate methods of PMSM sensorless control is needed. If the PMSM doesn't work overloaded, the method can be selected based on the motor speed. Selection methods must be under the needs. If the PMSM is used at low speed, we can choose the method by injection technique that works at stationary reference work. If the motor is used at both low and high speed, we can use the hybrid control method with a combination of I/ F constant and SMO with a smooth switching process, but the no-switching method is now being more widely researched. If PMSM more work at high speed, we prefer to choose the method that works at high speed: the modification or combination of two or more conventional methods.

\section{REFERENCES}

[1] M. Yilmaz, "Limitations/capabilities of electric machine technologies and modeling approaches for electric motor design and analysis in plug-in electric vehicle applications," Renewable and Sustainable Energy Reviews, vol. 52, pp. 80-99, 2015. https://doi.org/10.1016/j.rser.2015.07.033

[2] S. Singh and A. Tiwari, "Various techniques of sensorless speed control of PMSM: A review," in 2017 Second International Conference on Electrical, Computer and Communication Technologies (ICECCT), 2017, pp. 1-6. https://doi.org/10.1109/icecct.2017.8117995

[3] P. Pillay and R. Krishnan, "Application characteristics of permanent magnet synchronous and brushless DC motors for servo drives," IEEE Transactions on industry applications, vol. 27, pp. 986-996, 1991. https://doi.org/10.1109/28.90357

[4] S.-K. Sul, control of electric machine drive systems vol. 88: John Wiley \& Sons, 2011.

[5] J. Agrawal and S. Bodkhe, "Low speed sensorless control of PMSM drive using high frequency signal injection," in 2015 Annual IEEE India Conference (INDICON), 2015, pp. 1-6. https://doi.org/10.1109/indicon.2015.7443383

[6] O. M. Arafa, G. A. A. Aziz, M. I. A. El-Sebah, and A. A. Mansour, "Observer-based sensorless speed control of PMSM: A focus on drive's startup," Journal of Electrical Systems and Information Technology, vol. 3, pp. 181209, 2016. https://doi.org/10.1016/j.jesit.2015.05.004

[7] K. S. Gaeid, H. W. Ping, M. Khalid, and A. Masaoud, "Sensor and sensorless fault tolerant control for induction motors using a wavelet index," Sensors, vol. 12, pp. 4031-4050, 2012. https://doi.org/10.3390/s120404031

[8] A. A. Bobtsov, A. A. Pyrkin, R. Ortega, S. N. Vukosavic, A. M. Stankovic, and E. V. Panteley, "A robust globally convergent position observer for the permanent magnet synchronous motor," Automatica, vol. 61, pp. 47-54, 2015. https://doi.org/10.1016/j.automatica.2015.07.032

[9] M. Dursun, A. F. Boz, M. Kale, and M. Karabacak, "Sensorless control application of PMSM with a novel adaptation mechanism," Neural Computing and Applications, pp. 1-17, 2016. https://doi.org/10.1007/s00521-0162384-7

[10] S. Chen, Y. Luo, and Y. Pi, "PMSM sensorless control with separate control strategies and smooth switch from low speed to high speed," ISA transactions, vol. 58, pp. 650-658, 2015. https://doi.org/10.1016/j.isatra.2015.07.013

[11] A. Arias, C. Ortega, J. Zaragoza, J. Espina, and J. Pou, "Hybrid sensorless permanent magnet synchronous machine four quadrant drive based on direct matrix converter," International Journal of Electrical Power \& Energy Systems, vol. 45, pp. 78-86, 2013. https://doi.org/10.1016/j.ijepes.2012.08.073

[12] G. Wang, M. Valla, and J. Solsona, "Position sensorless permanent magnet synchronous machine drives-A review," IEEE Transactions on Industrial Electronics, vol. 67, pp. 5830-5842, 2019. https://doi.org/10.1109/tie.2019.2955409

[13] D. Xu, B. Wang, G. Zhang, G. Wang, and Y. Yu, "A review of sensorless control methods for AC motor drives," CES Transactions on electrical machines and systems, vol. 2, pp. 104-115, 2018. https://doi.org/10.23919/tems.2018.8326456

[14] G. Zhang, G. Wang, and D. Xu, "Saliency-based position sensorless control methods for PMSM drives-A review," Chinese Journal of Electrical Engineering, vol. 3, pp. 14-23, $2017 . \quad$ DOI: https://doi.org/10.23919/cjee.2017.8048408

[15] Q. Yuan, Z. Yang, F. Lin, and H. Sun, "Sensorless control of permanent magnet synchronous motor with stator flux estimation," Journal of Computers, vol. 8, pp. 108-112, 2013. https://doi.org/10.4304/jcp.8.1.108-112

[16] B. Akin, M. Bhardwaj, and J. Warriner, "Sensorless Field Oriented Control of 3-Phase Permanent Magnet Synchronous Motors," Texas Instruments, Application Notes, 2013.

[17] X. Luo, Q. Tang, A. Shen, and Q. Zhang, "PMSM Sensorless Control by Injecting HF Pulsating Carrier Signal Into Estimated Fixed-Frequency Rotating Reference Frame," IEEE Transactions on Industrial Electronics, vol. 63, pp. 2294-2303, 2016. https://doi.org/10.1109/tie.2015.2505679

[18] J. Xing, Z. Qin, C. Lin, and X. Jiang, "Research on Startup Process for Sensorless Control of PMSMs Based on IF Method Combined With an Adaptive Compensator," IEEE Access, vol. 8, pp. 70812-70821, 2020. https://doi.org/10.1109/access.2020.2987343

[19] X. Jin, R. Ni, W. Chen, F. Blaabjerg, and D. Xu, "High-frequency voltage-injection methods and observer design for initial position detection of permanent magnet synchronous machines," IEEE Transactions on Power Electronics, vol. 33, pp. 7971-7979, 2017. https://doi.org/10.1109/tpel.2017.2773094

[20] X. Song, J. Fang, B. Han, and S. Zheng, "Adaptive compensation method for high-speed surface PMSM sensorless drives of EMF-based position estimation error," IEEE Transactions on Power Electronics, vol. 31, pp. 1438-1449, 2015. https://doi.org/10.1109/tpel.2015.2423319 
[21] G. Xie, K. Lu, S. K. Dwivedi, J. R. Rosholm, and F. Blaabjerg, "Minimum-voltage vector injection method for sensorless control of PMSM for low-speed operations," IEEE Transactions on Power Electronics, vol. 31, pp. 1785-1794, 2015. https://doi.org/10.1109/tpel.2015.2426200

[22] G. Wang, J. Kuang, N. Zhao, G. Zhang, and D. Xu, "Rotor position estimation of PMSM in low-speed region and standstill using zero-voltage vector injection," IEEE Transactions on Power Electronics, vol. 33, pp. 7948-7958, 2017. https://doi.org/10.1109/tpel.2017.2767294

[23] S. Wang, K. Yang, and K. Chen, "An improved position-sensorless control method at low speed for PMSM based on high-frequency signal injection into a rotating reference frame," IEEE Access, vol. 7, pp. 86510-86521, 2019. https://doi.org/10.1109/access.2019.2925214

[24] H. Li, X. Zhang, S. Yang, and S. Liu, "Unified Graphical Model of High-Frequency Signal Injection Methods for PMSM Sensorless Control," IEEE Transactions on Industrial Electronics, vol. 67, pp. 4411-4421, 2019. https://doi.org/10.1109/tie.2019.2924863

[25] K. Scicluna, C. S. Staines, and R. Raute, "Sensorless Low/Zero Speed Estimation for Permanent Magnet Synchronous Machine Using a Search-Based Real-Time Commissioning Method," IEEE Transactions on Industrial Electronics, vol. 67, pp. 6010-6018, 2020. https://doi.org/10.1109/tie.2020.2965483

[26] C. Wu, Y. Zhao, and M. Sun, "Enhancing low-speed sensorless control of PMSM using phase voltage measurements and online multiple parameter identification," IEEE Transactions on Power Electronics, vol. 35, pp. 10700-10710, 2020. https://doi.org/10.1109/tpel.2020.2978200

[27] M. A. Hoque, "Speed and position sensorless permanent magnet synchronous motor drives," Proceedings of Canadian Conference on Electrical and Computer Engineering CCECE-94, 1994. https://doi.org/10.1109/ccece.1994.405845

[28] D. Yousfi and M. El Adnani, "Indirect position and speed sensing for PMSM sensorless control," in 2007 th Internatonal Conference on Power Electronics, 2007, pp. 817-822. https://doi.org/10.1109/icpe.2007.4692500

[29] B. W. Harini, F. Husnayain, A. Subiantoro, and F. Yusivar, "A SYNCHRONIZATION LOSS DETECTION METHOD FOR PMSM SPEED SENSORLESS CONTROL," Jurnal Teknologi, vol. 82, 2020. https://doi.org/10.11113/jt.v82.14369

[30] J. W. Finch and D. Giaouris, "Controlled AC electrical drives," IEEE Transactions on Industrial Electronics, vol. 55, pp. 481-491, 2008. https://doi.org/10.1109/tie.2007.911209

[31] M. Naidu and B. K. Bose, "Rotor position estimation scheme of a permanent magnet synchronous machine for high performance variable speed drive," in Conference Record of the 1992 IEEE Industry Applications Society Annual Meeting, 1992, pp. 48-53. https://doi.org/10.1109/ias.1992.244466

[32] M. Geethu and P. Kunjumon, "Sensorless adaptive PID speed control for permanent magnet synchronous motor drives," in 2016 International Conference on Emerging Technological Trends (ICETT), 2016, pp. 1-6. https://doi.org/10.1109/icett.2016.7873716

[33] L. Tian, Y. He, M. Lu, Y. Wang, and Y. Hu, "Sensorless Speed Control of High-Speed Permanent Magnet Synchronous Motor based on Model Reference Adaptive System," in 2019 Chinese Control Conference (CCC), 2019, pp. 3126-3131. https://doi.org/10.23919/chicc.2019.8865365

[34] A. Accetta, M. Cirrincione, M. Pucci, and G. Vitale, "Closed-loop MRAS speed observer for linear induction motor drives," IEEE Transactions on Industry Applications, vol. 51, pp. 2279-2290, 2014. https://doi.org/10.1109/tia.2014.2375377

[35] J. Yang, W. Tang, G. Zhang, Y. Sun, S. Ademi, F. Blaabjerg, et al., "Sensorless control of brushless doubly fed induction machine using a control winding current MRAS observer," IEEE Transactions on Industrial Electronics, vol. 66, pp. 728-738, 2018. https://doi.org/10.1109/tie.2018.2831168

[36] W.-H. Li, Z.-Y. Chen, and W.-P. Cao, "Simulation research on optimization of permanent magnet synchronous motor sensorless vector control based on MRAS," in 2012 International Conference on Wavelet Active Media Technology and Information Processing (ICWAMTIP), 2012, pp. 350-355. https://doi.org/10.1109/icwamtip.2012.6413511

[37] N. H. Saad, A. A. El-Sattar, and M. A. Gad, "Sensorless Field Oriented Control Based on Improved MRAS Speed Observer for Permanent Magnet Synchronous Motor Drive," in 2016 Eighteenth International Middle East Power Systems Conference (MEPCON), 2016, pp. 991-998. https://doi.org/10.1109/mepcon.2016.7837017

[38] Z. Liao, Q. Zhao, X. Zhang, and L. Cai, "Improved Permanent Magnet Synchronous Motor Control System Based on Position Sensorless Technology," in 2018 2nd IEEE Advanced Information Management, Communicates, Electronic and Automation Control Conference (IMCEC), 2018, pp. 1-2128. https://doi.org/10.1109/imcec.2018.8469760

[39] S. S. Badini and V. Verma, "A Novel MRAS Based Speed Sensorless Vector Controlled PMSM Drive," in 2019 54th International Universities Power Engineering Conference (UPEC), 2019, pp. 1-6. https://doi.org/10.1109/upec.2019.8893607

[40] O. C. Kivanc and S. B. Ozturk, "Sensorless PMSM drive based on stator feedforward voltage estimation improved with MRAS multiparameter estimation," IEEE/ASME Transactions on Mechatronics, vol. 23, pp. 1326-1337, 2018. https://doi.org/10.1109/tmech.2018.2817246

[41] H. Wang, X. Ge, and Y.-C. Liu, "Second-order sliding-mode MRAS observer-based sensorless vector control of linear induction motor drives for medium-low speed maglev applications," IEEE Transactions on Industrial Electronics, vol. 65, pp. 9938-9952, 2018. https://doi.org/10.1109/tie.2018.2818664 
[42] D. Yousfi, A. Halelfadl, and M. El Kard, "Review and evaluation of some position and speed estimation methods for PMSM sensorless drives," in Multimedia Computing and Systems, 2009. ICMCS'09. International Conference on, 2009, pp. 409-414. https://doi.org/10.1109/mmcs.2009.5256662

[43] C. L. Baratieri and H. Pinheiro, "New variable gain super-twisting sliding mode observer for sensorless vector control of nonsinusoidal back-EMF PMSM," Control Engineering Practice, vol. 52, pp. 59-69, 2016. https://doi.org/10.1016/j.conengprac.2016.04.003

[44] M. Zolfaghari, S. A. Taher, and D. V. Munuz, "Neural network-based sensorless direct power control of permanent magnet synchronous motor," Ain Shams Engineering Journal, vol. 7, pp. 729-740, 2016. DOI: https://doi.org/10.1016/j.asej.2016.01.002

[45] O. Aydogmus and S. Sünter, "Implementation of EKF based sensorless drive system using vector controlled PMSM fed by a matrix converter," International Journal of Electrical Power \& Energy Systems, vol. 43, pp. 736743, 2012. https://doi.org/10.1016/j.ijepes.2012.06.062

[46] A. Hassan, A. El-Sawy, Y. Mohamed, and E. Shehata, "Sensorless sliding mode torque control of an IPMSM drive based on active flux concept," Alexandria Engineering Journal, vol. 51, pp. 1-9, 2012. https://doi.org/10.1016/j.aej.2012.07.001

[47] H. Kim, J. Son, and J. Lee, "A high-speed sliding-mode observer for the sensorless speed control of a PMSM," IEEE Transactions on Industrial Electronics, vol. 58, pp. 4069-4077, 2011. https://doi.org/10.1109/tie.2010.2098357

[48] L. Jarzebowicz, K. Karwowski, and W. J. Kulesza, "Sensorless algorithm for sustaining controllability of IPMSM drive in electric vehicle after resolver fault," Control Engineering Practice, vol. 58, pp. 117-126, 2017. https://doi.org/10.1016/j.conengprac.2016.10.004

[49] E. G. Shehata, "Speed sensorless torque control of an IPMSM drive with online stator resistance estimation using reduced order EKF," International Journal of Electrical Power \& Energy Systems, vol. 47, pp. 378-386, 2013. https://doi.org/10.1016/j.ijepes.2012.10.068

[50] S. Bifaretti, V. Iacovone, A. Rocchi, P. Tomei, and C. Verrelli, "Nonlinear speed tracking control for sensorless PMSMs with unknown load torque: From theory to practice," Control Engineering Practice, vol. 20, pp. 714-724, 2012. https://doi.org/10.1016/j.conengprac.2012.03.010

[51] A. Accetta, M. Cirrincione, and M. Pucci, "TLS EXIN based neural sensorless control of a high dynamic PMSM," Control Engineering Practice, vol. 20, pp. 725-732, 2012. https://doi.org/10.1016/j.conengprac.2012.03.012

[52] Y. Iwaji, R. Takahata, T. Suzuki, and S. Aoyagi, "Position Sensorless Control Method at Zero-Speed Region for Permanent Magnet Synchronous Motors Using the Neutral Point Voltage of Stator Windings," IEEE Transactions on Industry Applications, vol. 52, pp. 4020-4028, 2016. https://doi.org/10.1109/tia.2016.2582118

[53] W. Xu, Y. Jiang, C. Mu, and F. Blaabjerg, "Improved nonlinear flux observer-based second-order SOIFO for PMSM sensorless control," IEEE Transactions on Power Electronics, vol. 34, pp. 565-579, 2018. DOI: https://doi.org/10.1109/tpel.2018.2822769

[54] H. Li, X. Zhang, S. Liu, and C. Xu, "Hybrid Sensorless Control Based on I/F and Sliding Mode Observer Using Current Nonlinear Regulation for PMSM Drives," in 2019 22nd International Conference on Electrical Machines and Systems (ICEMS), 2019, pp. 1-5. https://doi.org/10.1109/icems.2019.8921505

[55] D. Raca, P. Garcia, D. D. Reigosa, F. Briz, and R. D. Lorenz, "Carrier-signal selection for sensorless control of PM synchronous machines at zero and very low speeds," IEEE Transactions on Industry Applications, vol. 46, pp. 167178, 2009. https://doi.org/10.1109/08ias.2008.225

[56] B. W. Harini, A. Subiantoro, and F. Yusivar, "Stability of the Rotor Flux Oriented Speed Sensorless Permanent Magnet Synchronous Motor Control," in 2018 IEEE 27th International Symposium on Industrial Electronics (ISIE), 2018, pp. 283-289. https://doi.org/10.1109/isie.2018.8433862

[57] B. Yan, X. Wang and Y. Yang, "Starting Performance Improvement of Line-Start Permanent-Magnet Synchronous Motor Using Composite Solid Rotor," in IEEE Transactions on Magnetics, vol. 54, no. 3, pp. 1-4, March 2018. https://doi.org/10.1109/TMAG.2017.2753238

[58] B. W. Harini, Subiantoro, A., Yusivar, F., "Study of Speed Sensorless Permanent Magnet Synchronous Motor (PMSM) Control Problem Due to Braking during Steady State Condition " presented at the 2017 15th International Conference on Quality in Research (QiR) : International Symposium on Electrical and Computer Engineering Bali, Indonesia, 2017. https://doi.org/10.1109/qir.2017.8168479

\section{BIOGRAPHY OF AUTHOR}

Bernadeta Wuri Harini, Lecturer of Electrical Engineering Department, Universitas Sanata Dharma, Yogyakarta. The research fields are the control system. Email: wuribernard@usd.ac.id 